\title{
Pulmonary blastoma: a report of two cases and a review of the literature
}

\author{
A. KEN NEDY a nd A. L. PRIOR ${ }^{1}$ \\ Departments of Pathology and Thoracic Surgery, United Sheffield Hospitals
}

\begin{abstract}
Kennedy, A. and Prior, A. L. (1976). Thorax, 31, 776-781. Pulmonary blastoma: a report of two cases and a review of the literature. Pulmonary blastoma is the rarest malignant tumour of the lung. Two more cases are reported and the literature is reviewed. The first case, a woman, is the longest recorded survivor. An examination of all the reported cases shows that the tumour is less common and less aggressive in women.
\end{abstract}

Pulmonary blastoma was first described as a histological entity by Barnard in 1952. A total of 28 cases have been reported. There is still controversy about the histogenesis of pulmonary blastoma, and there is uncertainty about the best method of treatment. The purpose of reporting these two cases is to discuss the experience accumulated in the diagnosis and treatment of this very rare disease.

\section{CASE 1}

Mrs. P.L., a 29-year-old woman, was admitted in July 1956 with a one-month history of dyspnoea and chest pain. A few days before her admission she suffered a paroxysm of coughing and brought up a lump of tissue with immediate relief of her symptoms. She had a previous history of pneumonia in infancy, one attack at 6 months of age and a second attack at 18 months.

Examination showed a fit young woman. Her blood pressure was $130 / 100 \mathrm{mmHg}$ and her pulse rate 80 beats per minute and regular. On auscultation there was reduced air entry to the left lower lobe. The haemoglobin was $16 \mathrm{~g} / \mathrm{dl}$ and the white cell count 10000 cells $/ \mathrm{mm}^{3}$. Chest radiography showed collapse of the left lower lobe. A bronchoscopy was performed and tumour was seen in the left lower lobe bronchus. A biopsy was taken which showed fibrosis and small clumps of cells which were interpreted as being 'oat-cell carcinoma'.

A left pneumonectomy was done and she made an uneventful recovery. The pathological findings are described below.

'Present address: 6161 Harry Hines Boulevard, Dallas, Texas, USA
She became pregnant in May 1957, and in 3 October 1957 a lump was found in the left breast. $\mathbb{\Phi}$ Excision biopsy of this showed that it was a $\vec{\oplus}$ secondary from the pulmonary blastoma. In December 1957 she delivered a full-term normal ${ }^{\circ}$ female child. Lactation was suppressed because of her history of pulmonary blastoma and metastasis in the left breast. In February 1959 she presented with an eight-month history of a recurrence in the left breast and left axillary lymph node. These $\varrho$ two lesions were excised locally and again $\overrightarrow{0}$ histology confirmed that they were secondaries 3 from the pulmonary blastoma. She became pregnant once more in June 1960 but this pregnancy was terminated in view of her history of multiple secondaries in the left breast and axilla. She was alive and well when last heard of in 1972.

PATHOLOGY The left lung contained a sphericalô tumour, $2.5 \mathrm{~cm}$ in diameter, which had an extension, $2 \times 1 \mathrm{~cm}$, protruding into the lumen of the 의 left main bronchus. The tumour had a biphasic $D$ structure and consisted of small glandular struc-을 tures embedded in a stroma of small spindle cells. N These spindle cells were associated with a good deal of collagen and did not include many mitotic $\widetilde{N}$ figures. The tubular and glandular component was $\omega$ lined by cubical or flattened cells and the spaces contained small quantities of acid mucin (Fig. 1). The bronchial biopsy specimen consisted only of $\mathbb{D}$ the spindle-cell component and it was this fact? that led to the erroneous preoperative diagnosis $\frac{T}{-}$ of oat-cell carcinoma.

The secondary tumour found in the breast (Fig. $\stackrel{\mathbb{\Omega}}{\stackrel{\$}{\circ}}$ 2 ) is interesting in that both the spindle-cell and $\stackrel{\Phi}{\varrho}$ 


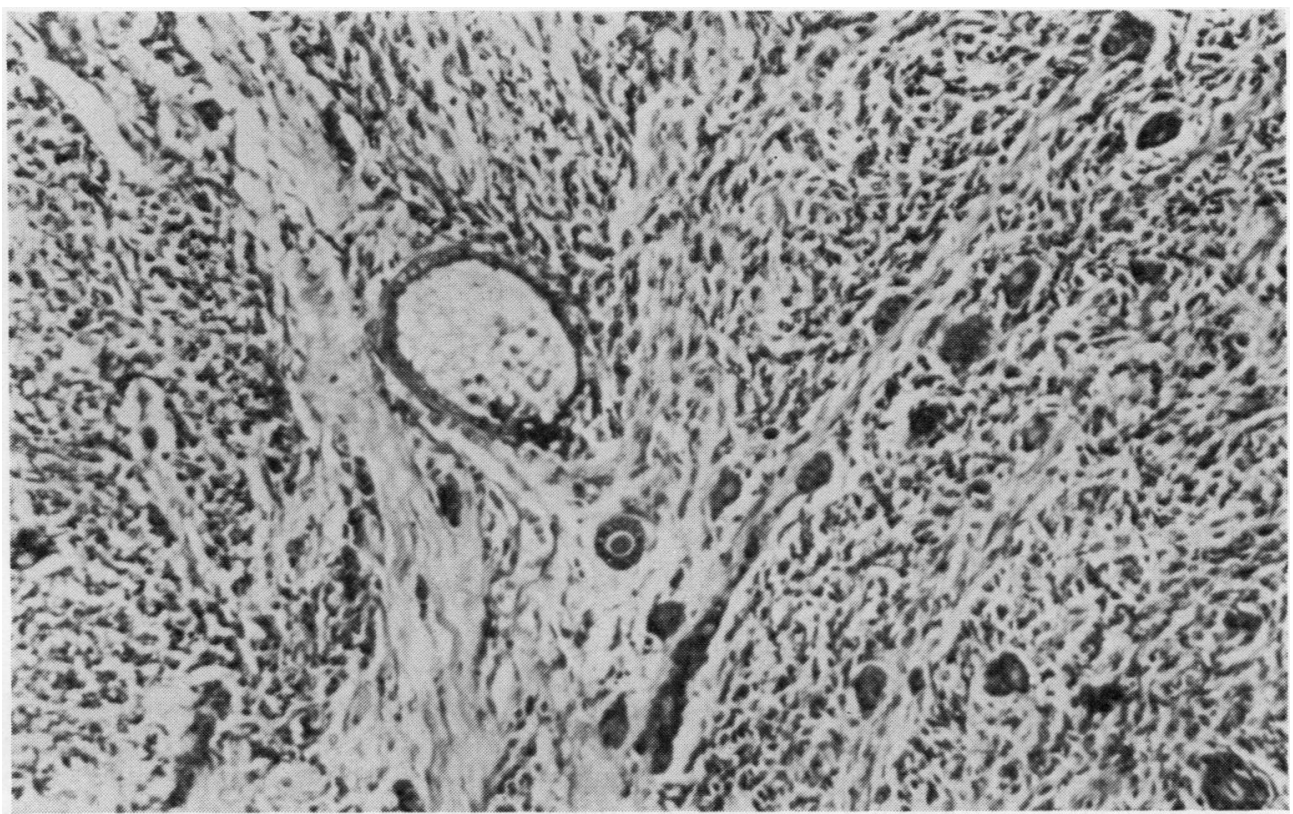

FIG. 1. Case 1. The tumour consists of sheets of spindle-cell stroma which contain small tubular or acinar structures lined by cubical epithelium. Haematoxylin and eosin $\times 100$.

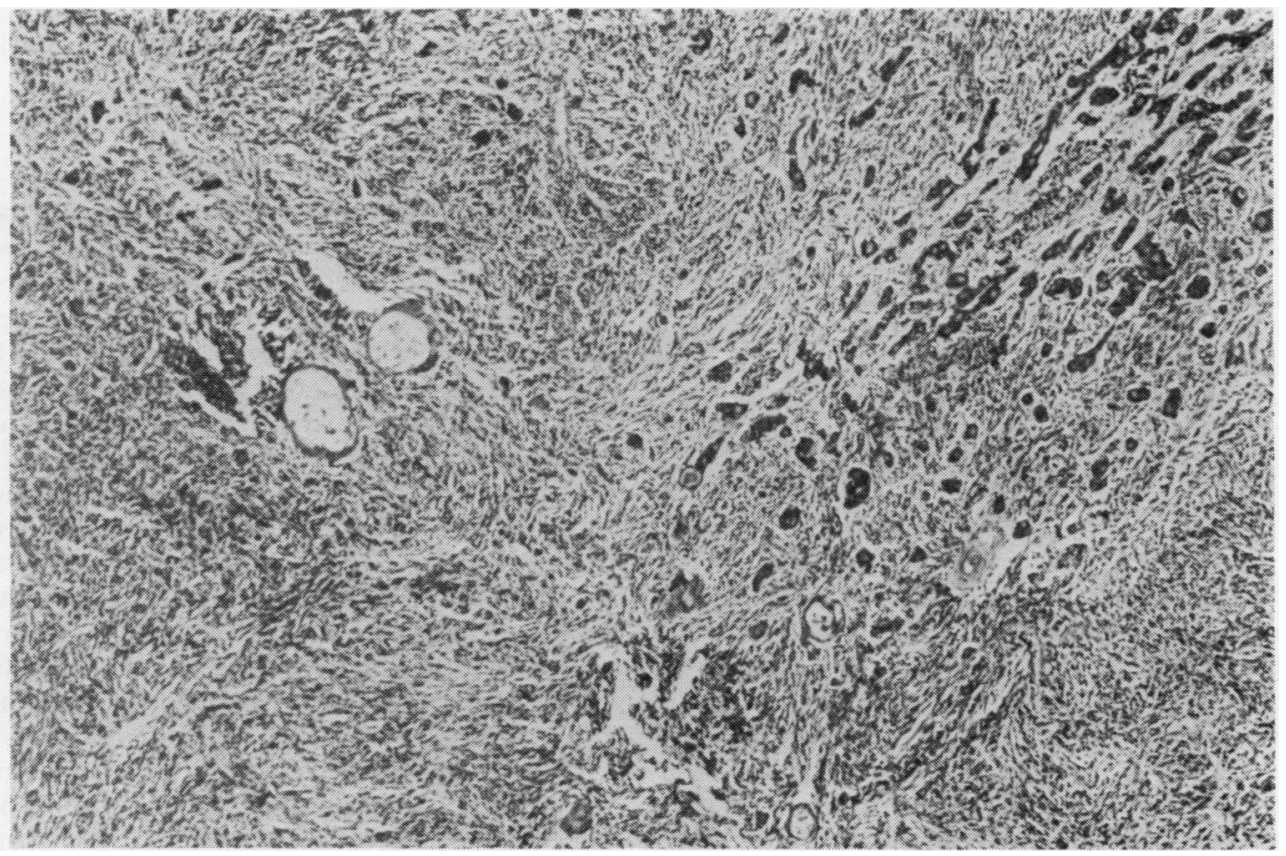

FIG. 2. Case 1. The secondary deposit of tumour removed from the breast and axillary nodes has a structure identical with that of the primary. $H$ and $E \times 40$. 
the glandular components of the tumour had metastasized.

\section{CASE 2}

Mr. R.M., a 27-year-old man, presented in February 1974 with a six-week history of left-sided chest pain and haemoptysis. He had a history of pneumonia when he was 17 years old. Since the age of 9 , he had smoked 25 to 30 cigarettes a day.

Examination showed a fit young man. His blood pressure was $130 / 80 \mathrm{mmHg}$ and pulse rate 60 per minute and regular. There was reduced air entry to the left upper lobe and reduced movement of the left upper chest wall. The haemoglobin was $13.6 \mathrm{~g} / \mathrm{dl}$ and white cell count 8000 cells $/ \mathrm{mm}^{3}$. Chest radiography showed a dense oval mass in the left upper lobe.

A needle biopsy was carried out and was interpreted as 'a well differentiated adenocarcinoma'. A left upper lobectomy was performed from which he made a smooth recovery. Examination of the specimen removed revealed that it was in fact a pulmonary blastoma. A full description of the histology is given below.

In August 1974 he presented with a recurrence locally in the left hilum. This was treated with deep radiotherapy; a total dose of 4200 rads (Co 60) were delivered to the left hemithorax. In addition, two seven-week courses of combined cytotoxic therapy (methotrexate, thiotepa, Vilve, and fluorouracil) were given. In December 1974 a course of Andreamycin was begun. Subsequent chest radiography showed no reduction in the size of the recurrence. In December 1975 he was admitted to hospital complaining of chest pain, headache, pain behind the left eye, and haematemesis. This settled down with bed rest, and the headache and pain behind the left eye were attributed to sinusitis. The patient died in May 1976. There had been no sign of regression of the recurrent tumour in response to radiotherapy and cytotoxic drugs.

PATHOLOGY In the upper lobe of the lung there was a bulky ovoid mass, $6 \mathrm{~cm}$ in maximal diameter (Fig. 3). This consisted of soft homogeneous white $t$ :ssue with areas of necrosis. No obvious bronchial connection was demonstrated, and the bronchi appeared to be stretched round the tumour rather than passing into it.

This tumour also had a biphasic structure (Fig. 4) consisting of glands lined by cubical cells embedded in a frankly neoplastic spindle-cell stroma.

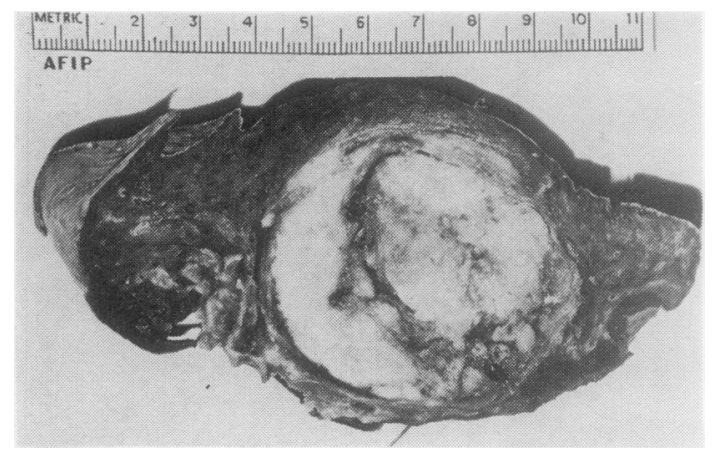

FIG. 3. Case 2. A slice of the resected upper lobe of the left lung. The tumour is crumbling and partly necrotic. The bronchi appear to be stretched around the periphery.

The stroma appeared myxomatous and formed whorls and nodules of almost chondroid appearance similar to those seen in other embryonic tumours such as teratomas of the testis. The glands were lined sometimes by tall columnar cells and sometimes cubical cells arranged in two layers (Fig. 5). The needle biopsy had consisted entirely of these glandular areas and the spindlecell element was not represented. Parts of the $\unrhd$ tumour were clearly invading blood vessels. The $\overrightarrow{\overrightarrow{0}}$ lymph nodes were not involved.

\section{DISCUSSION}

Pulmonary blastoma is the rarest malignant tumour of the lung. Twenty-eight cases have been $\underset{x}{ }$ reported in the literature. Karcioglu and Someren (1974) found 21 cases. A further seven cases have been reported and are summarized in the Table.

The characteristic feature of these tumours is their biphasic pattern consisting of a spindle-cell 음 stroma containing glandular structures. Where $>$ both of these elements can be identified the diag- 을 nosis is easy provided that the possibility of a N metastasis of a teratoma from some other site can $N$ be excluded. The true nature of these mixed tu- $N$ mours remains debatable, and many authors deny their blastomatous origin (Peacock and Whitwell, O 1976). However, there is no doubt that they are 0 fully malignant and that both components of the tumour are capable of metastasis. In our first case $\stackrel{\oplus}{+}$ the tumour had maintained its histological appear- $\underline{T}$ ance when deposits were removed from the $\stackrel{\vec{P}}{\mathbb{P}}$ breast and lymph nodes nearly three years after $\stackrel{\mathbb{D}}{\Omega}$ pneumonectomy. 


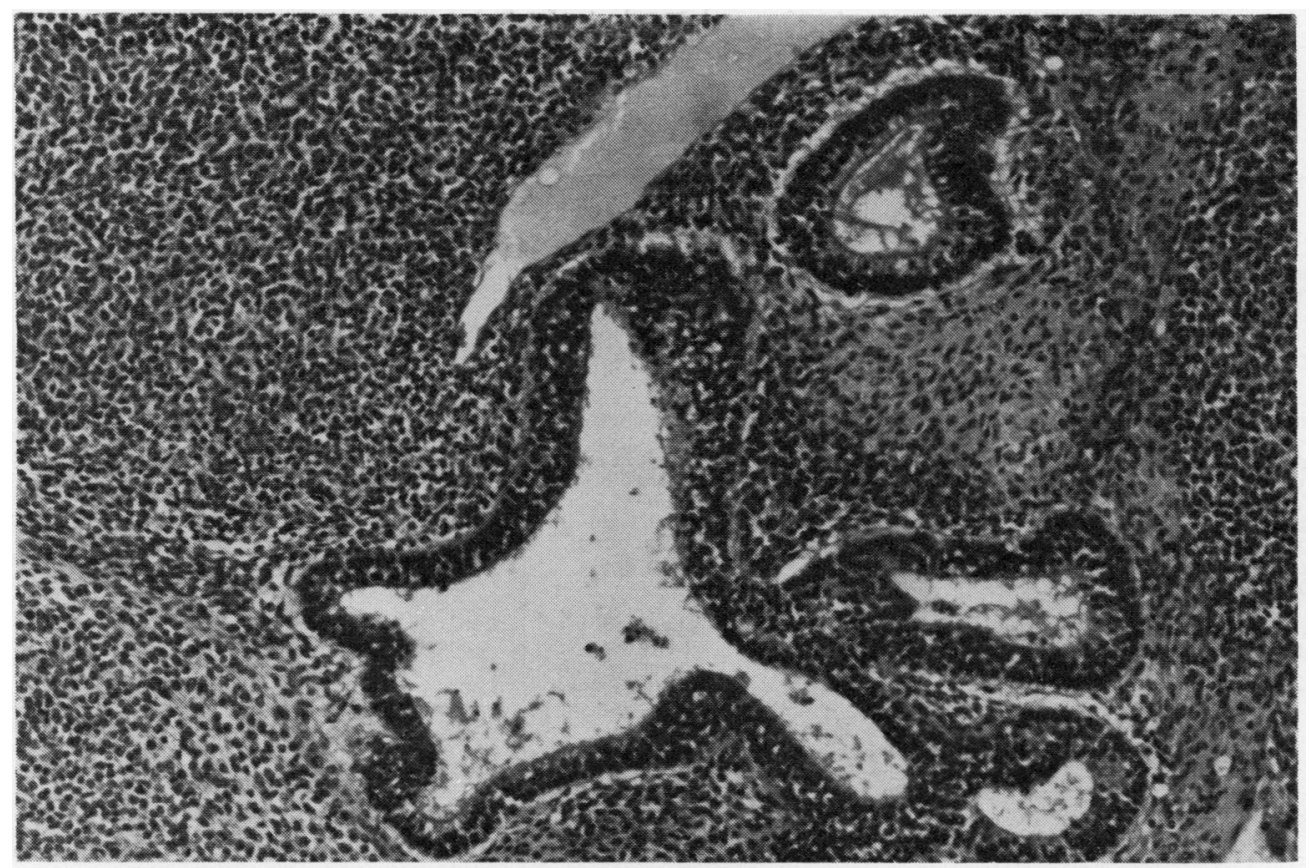

FIG. 4. Case 2. The tumour is composed of irregular glandular spaces lined by low columnar epithelium and set in a stroma of round cells and spindle cells. $H$ and $E \times 100$.

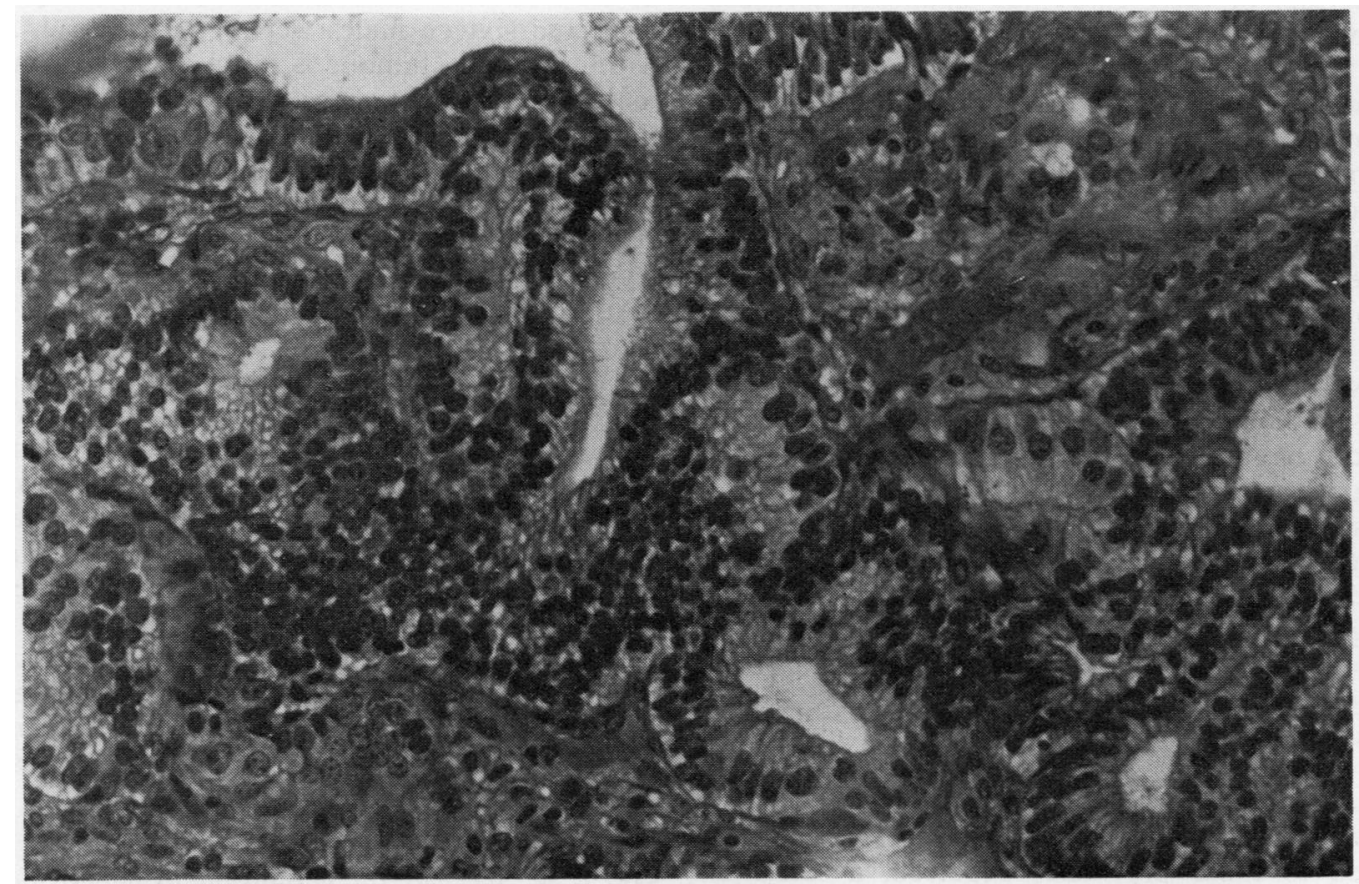

FIG. 5. Case 2. The needle biopsy consists of tightly packed glands lined by columnar epithelium. In some glands the arrangement of the nuclei gives the impression of a double-layered epithelium $H$ and $E \times 400$. 
T A B L E

REVIEW OF NINE CASES OF PULMONARY BLASTOMA REPORTED SINCE THE REVIEW OF KARCIOGLU AND SOMEREN

\begin{tabular}{|c|c|c|c|c|c|c|}
\hline Author & $\begin{array}{c}\text { Patient's } \\
\text { Sex and Age }\end{array}$ & Size and Location & $\begin{array}{l}\text { Symptoms and } \\
\text { Signs }\end{array}$ & Treatment & Metastases & Follow-up \\
\hline $\begin{array}{l}\text { Ray Chaudhuri et al. } \\
\text { (1972) }\end{array}$ & $\begin{array}{l}\mathbf{M} \\
\mathbf{3 2}\end{array}$ & $\begin{array}{l}10 \times 8 \times 3 \mathrm{~cm} \\
\text { Fissure between } \\
\text { RUL and RLL }\end{array}$ & $\begin{array}{l}\text { Fever, } \\
\text { right-sided } \\
\text { chest pain, } \\
\text { and dysnnoea }\end{array}$ & Excision & None & Alive \\
\hline Davis et al. (1972) & $\begin{array}{l}\mathbf{M} \\
58\end{array}$ & $\begin{array}{l}50 \times 30 \times 40 \mathrm{~cm} \\
\text { RLL }\end{array}$ & Dyspnoea & $\begin{array}{l}\text { Right } \\
\text { pneumonectomy }\end{array}$ & None & $\begin{array}{l}\text { Died } 11 \mathrm{mth} \\
\text { postop. cardiac } \\
\text { infarction }\end{array}$ \\
\hline Davis et al. (1972) & $\begin{array}{l}M \\
40\end{array}$ & $\begin{array}{l}7 \mathrm{~cm} \text { diam. } \\
\text { RUL }\end{array}$ & & $\begin{array}{l}\text { Right } \\
\text { pneumonectomy }\end{array}$ & & $\begin{array}{l}\text { Died postop. } \\
\text { haemorrhage }\end{array}$ \\
\hline $\begin{array}{l}\text { Karcioglu and Someren } \\
\text { (1974) }\end{array}$ & $\begin{array}{l}M \\
48\end{array}$ & $\begin{array}{l}17 \mathrm{~cm} \text { diam. } \\
\text { RML and RUL }\end{array}$ & $\begin{array}{l}\text { Dyspnoea and } \\
\text { bilateral chest } \\
\text { pain }\end{array}$ & & None & $\begin{array}{l}\text { Died } 4 \text { mth after } \\
\text { presentation }\end{array}$ \\
\hline $\begin{array}{l}\text { Madhusudana et al. } \\
\text { (1974) }\end{array}$ & $\begin{array}{l}\mathrm{F} \\
30\end{array}$ & $\begin{array}{l}5 \times 10 \times 5 \mathrm{~cm} \\
\mathbf{R L L}\end{array}$ & $\begin{array}{l}\text { Pain in right } \\
\text { lower chest }\end{array}$ & $\begin{array}{l}\text { Right lower } \\
\text { lobectomy }\end{array}$ & & \\
\hline $\begin{array}{l}\text { Peacock and Whitwell } \\
\text { (1976) }\end{array}$ & F & 3 cm diam. & Cough & $\begin{array}{l}\text { Apical segment } \\
\text { resected }\end{array}$ & None & Alive $6 \mathrm{mth}$ later \\
\hline $\begin{array}{l}\text { Peacock and Whitwell } \\
\text { (1976) }\end{array}$ & $\begin{array}{l}\mathbf{M} \\
\mathbf{2 3}\end{array}$ & LUL and LLL & $\begin{array}{l}\text { Cough and } \\
\text { left-sided } \\
\text { pleuritic pain }\end{array}$ & $\begin{array}{l}\text { Left } \\
\text { pneumonectomy }\end{array}$ & None & $\begin{array}{l}\text { Died } 6 \mathrm{mth} \text { later, } \\
\text { massive } \\
\text { recurrence }\end{array}$ \\
\hline Present study & $\begin{array}{l}F \\
29\end{array}$ & $\begin{array}{l}2 \cdot 5 \mathrm{~cm} \text { diam. } \\
\text { with } 2 \times 1 \mathrm{~cm} \\
\text { extension into } \\
\text { bronchial } \\
\text { lumen } \\
\text { LLL }\end{array}$ & $\begin{array}{l}\text { Dyspnoea, chest } \\
\text { pain, and } \\
\text { cough }\end{array}$ & $\begin{array}{l}\text { Left } \\
\text { pneumonectomy }\end{array}$ & $\begin{array}{l}\text { Left breast } \\
\text { and left } \\
\text { axillary } \\
\text { lymph } \\
\text { node }\end{array}$ & $\begin{array}{l}\text { Alive more than } \\
16 \text { yr after } \\
\text { diagnosis }\end{array}$ \\
\hline Present study & $\begin{array}{l}\mathbf{M} \\
22\end{array}$ & $\begin{array}{l}6 \times 4 \cdot 5 \mathrm{~cm} \\
\text { LUL }\end{array}$ & $\begin{array}{l}\text { Chest pain and } \\
\text { haemoptysis }\end{array}$ & $\begin{array}{l}\text { Left upper } \\
\text { lobectomy }\end{array}$ & None & $\begin{array}{l}\text { Died } 2 \text { yr later, } \\
\text { massive } \\
\text { recurrence }\end{array}$ \\
\hline
\end{tabular}

Neither of these cases was diagnosed correctly by biopsy. In the first case there were two reasons for this. The bronchial biopsy contained only the spindle-cell element and the specimen was submitted at a time (1956) when the entity of pulmonary blastoma was not widely known. In retrospect the spindle cells were smaller and more elongated than in oat-cell carcinoma and more widely dispersed in collagenous fibres. It should also be stressed that a diagnosis of carcinoma of the lung in a non-smoker should always be carefully reconsidered no matter how alarming are the histological findings. In the second case, the needle biopsy contained only some of the glandular element but the glands were dissimilar to those of an adenocarcinoma in that the cells were often tall and columnar or arranged in several layers (Fig. 5). They resemble an embryonal type of tumour rather than an adenocarcinoma. The second case also had features which suggested that the prognosis was poor in that the spindle-cell stroma was cytologically malignant and vascular invasion was present. Neither of these features was present in the first case.

When these two cases described above are added to those previously reported, a series of 30 cases can be compiled. The age distribution ranges from 15 to 77 years. The tumour is more common in males (male : female ratio $23: 7$ ), and in the series of 30 cases, one female was reported dead and sixteen males were reported dead, indi- $\frac{0}{0}$

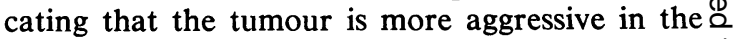
male. The longest survivor was a female who $\overrightarrow{0}$ lived at least 16 years. The longest male sur- $\exists$ vivor was alive after three years.

The main symptoms were pain, cough, haemoptysis, and dyspnoea. Each of the first three were equally common, occurring in about one-third of the patients, while dyspnoea occurred in one- $x$ quarter.

From this series of 30 patients it can be seen that the best treatment is radical excision of the $O$ primary. No patient has survived with radiotherapy and cytotoxic drugs. In our second case, $\frac{\circ}{7}$ there was no apparent regression after radio- $\rightarrow$ therapy and cytotoxic drugs for the left hilar recurrence. In view of the low female incidence of $N$ pulmonary blastoma, and the apparent slow progression of the tumour in females, endocrine 0 therapy might be of value. In our first case, recur- $\omega$ rence seemed to follow pregnancy and tumour inhibition seemed to be produced by suppressing lactation and terminating a pregnancy.

We should like to thank Mr. A. G. Norman and 0 Mr. J. W. Fawcett for permission to publish details $\bar{O}$ of their cases. We wish to acknowledge the assistance $\mathbb{\mathbb { D }}$ of Mrs. M. Rowe from the Department of Pathology $\underset{\mathbb{D}}{\mathbb{Q}}$ in producing the illustrations. 


\section{REFERENCES}

Barnard, W. G. (1952). Embryoma of lung. Thorax, 7, 299.

Davis, P. W., Briggs, J. C., Seal, R. M. E., and Storring, F. K. (1972). Benign and malignant mixed tumours of the lung. Thorax, 27, 657.

Karcioglu, Z. A. and Someren, A. O. (1974). Pulmonary blastoma: a case report and review of the literature. American Journal of Clinical Pathology, 61, 287.

Madhusudana, Rao, K., Gupta, R. P., Das. P. B.,
John, S., and Walter, A. (1974). Pulmonary blastoma: a case report. Thorax, 29, 138.

Peacock, M. J. and Whitwell, F. (1976). Pulmonary blastoma. Thorax, 31, 197.

Ray Chaudhuri, M., Eastham, W. N., and Fredriksz, P. A. (1972). Pulmonary blastoma with diverse mesenchymal proliferation. Thorax, 27, 487.

Requests for reprints to: A. L. Prior, FRCS, 6161 Harry Hines Boulevard, Dallas, Texas, USA. 